\title{
Blended Learning Technology "Flipped Class" in the System of Higher Vocational Education
}

\author{
Svetlana Belovitskay ${ }^{1, *}$, Tatiana Guseva $^{2}$, Daria Demicheva $^{2}$, Irina Shatokhina ${ }^{2}$, and Elena \\ Shcherbina ${ }^{2}$ \\ ${ }^{1}$ DonStateTechnicalUniversity 1, Gagarin sq., 344003 Rostov-on-Don, Russia; \\ ${ }^{2}$ Southern Federal University 105/42, Bolshaya Sadovaya st., 344006 Rostov-on-Don, Russia
}

\begin{abstract}
This article is devoted to the implementation of the blended learning technology " Flipped Class" into the educational process of higher vocational education. From the position of the systemic approach, the authors' view on the development of the competitiveness of the future specialist with the help of traditional (classroom) and digital (distance) forms of training is revealed; the necessary pedagogical conditions for using the " Flipped Class " blended learning technology in higher vocational education are described. The authors present the peculiarity of organizing the educational process with the use of the " Flipped Class " technology. The article justifies the importance and relevance of this educational technology application due to the world socio-economic challenges. The authors of the study conclude that the implementation of the " Flipped Class" technology causes improvement of the forms and methods of the educational activity aiming professional development of future competitive professionals in the sphere of the agro-industrial complex. A structural model of organizing higher vocational education with the use of the " Flipped Class " blended learning technology was worked out and substantiated. The pedagogical conditions of using this technology are described in the article.
\end{abstract}

\section{Introduction}

Higher professional education is responsible to the state and society for the quality of training specialists in various fields. Due to the changes taking place in the modern world, the Russian system of higher professional education is forced to make adjustments and expand the range of technologies aimed at the professional formation of future specialists. For example, by the Order of the National Agency for the Development of Qualifications of 26 June, 2020 No 42/20-PR " On the Approval of the Names and Requirements for Qualifications of the Agro-Industrial Complex (Agricultural Industry)"new qualification names and requirements for qualifications (qualification level, labor functions, additional characteristics of the profession) are approved [1].

It should be noted that world economic development and the labor market are developing disproportionately. In this regard, the system of higher vocational education has a predominantly intensive way of creating and implementing innovative educational

\footnotetext{
${ }^{*}$ Corresponding author: belovickaja-svetlana@rambler.ru
} 
technologies. The use of innovative technologies in the educational process affects the quality of training specialists and determines the professional competitiveness of a modern graduate.

M.V. Stanislavskaya and M.S. Levkovskaya present the tools used to develop management decisions [2]. Thus the modern system of higher vocational education intensively uses revolutionary achievements in the application of Internet technologies.

It is in the system of higher vocational education that the future specialist acquires a "skill" of competitiveness: knowledge, skills and abilities, as well as willingness to solve various problems in professional activity.

One of the conditions for the professional development of the personality in the modern world is the use of various educational technologies in the educational process. The solution of this problem is possible through the implementation of the " Flipped Class " blended learning technology into the higher vocational education system. This educational technology has become widespread in modern educational practice. Its purpose is the active use of distance learning elements, the use of electronic educational resources and Internet resources. The application of this technology is relevant in the context of the restrictive measures connected with the pandemic 2020-2021 and suggests a new approach to the organization of vocational training. Being part of problem-oriented learning, this method has greater flexibility, provides greater students' involvement into the educational process, allows educators to form a dynamic and creative environment in which students learn to think critically and solve learning problems in collaboration [3]. Therefore, the educational technology " Flipped Class " is focused on the development of research and critical thinking of students, which is important in the formation of a competitive professional.

In the scientific research "La pédagogie inversée. Enseigner autrement dans le supérieur avec la classe inversée" Dumont A. and Berthiaume D. demonstrate that the blended learning isn't a new method, it represents a new mentality aiming optimization of classroom work with students thanks to the out-of-class activity directed to in-depth study of a subject [4]. At the same time the professional task of the lecture changes. The basic task is to create the pedagogical conditions motivating students to solve learning-and-professional problems while independent searching and analyzing knowledge. Critical judgment of the gained knowledge and intellectual response of the students to the educational contents is one of the most important conditions of the professional formation. The use of the technology of blended learning " Flipped Class " for training qualified specialists meeting social world changes causes complex structure of this phenomenon (fig. 1). 


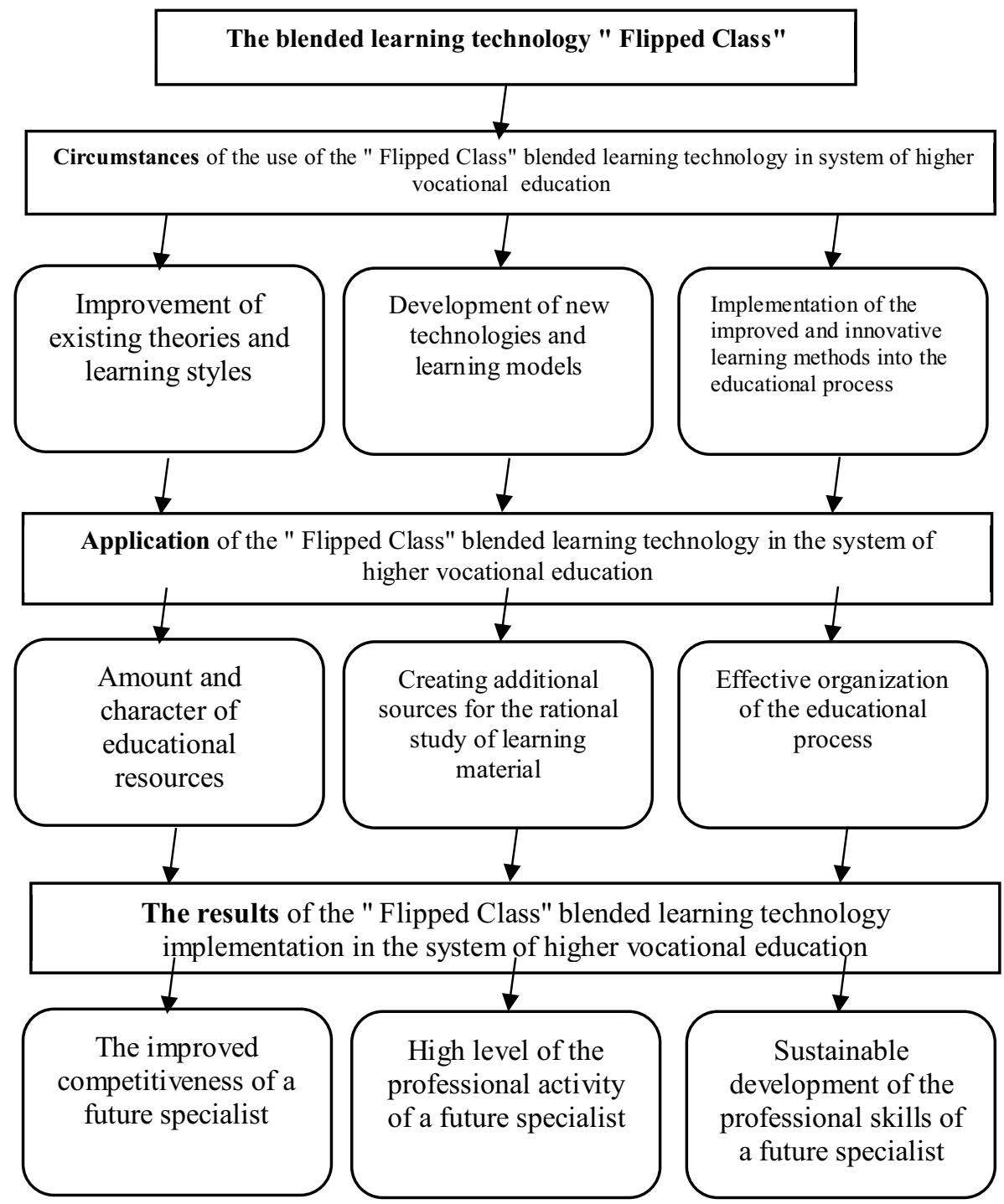

Fig 1. Structural Model of the Use of Blended Learning Technology " Flipped Class "

The above presented structural model of the use of the " Flipped Class " blended learning technology in the system of higher vocational education is primarily determined by the circumstances of its implementation. This actualizes the need to improve existing learning technologies in modern educational practice, and also explains the need to develop new learning models. Improved learning models will contribute to the quality of training future competitive professionals.

The effectiveness of the implementation of blended learning technologies into the future specialists training presupposes the creation of additional channels for students to get educational material, as well as determining the amount and character of the educational resources proposed to the students.

Thus, the use of the " Flipped Class " blended learning technology in the educational practice of the system of higher vocational education allows us to distinguish the following determinants of the professional formation of the personality: 
- firstly, high level of competitiveness of the future specialist;

- secondly, high level of the professional activity of a future specialist;

- thirdly, sustainable development of the professional skills of a future specialist.

The purpose of the article is to analyze the effectiveness of the use of the "Flipped Class " blended learning technology in the system of higher vocational education for the professional formation of a competitive specialist in various fields of activity. The problem of the study is to establish the relationship between the training of a future competitive specialist and the proposed mobilization course of the development of higher vocational education at the federal and international levels. Consequently, the hypothesis of the study is as follows: it is possible that the use of the blended learning technology " Flipped Class " in the system of higher vocational education will contribute to the effectiveness of the training of future competitive specialists.

\section{Concept and methodology of the study}

The empirical array contains the texts of the passports of regulatory documents of the federal level: the Federal Law "On the Education in the Russian Federation", 2012/12/29 No 273FL, adopted by the State Duma on December 21, 2012 and approved by the Federation Council on December 26, 2012, (edited on June 31, 2020) and (with changes and additions entered into force on September 1, 2020); Labor Code of the Russian Federation 2001/12/30 No 197-FL, adopted by the State Duma on December 21, 2001 and approved by the Federation Council on December 26, 2001 (with changes and additions entered into force on August 13, 2020); Decree of the Government of the Russian Federation of 07.12.2020 N 2040 "On conducting an experiment on the introduction of a digital educational environment" (together with the "Regulation on conducting an experiment on the implementation of a digital educational environment on the territory of certain constituent entities of the Russian Federation"); Decree of the Government of the Russian Federation dated 26.12.2017 N 1642 (ed. From 11.08.2020) "On Approval of the State Program of the Russian Federation" Development of Education "; Federal State Educational Standard of Higher Education bachelor's degree in the field of training 44.03.01 "Pedagogical Education" (Registered in the Ministry of Justice of the Russian Federation 2018/03/15 No 50362), approved by the Order of the Ministry of Education and Science of the Russian Federation on February 22, 2018 No 121; Order of the Ministry of Education and Science of the Russian Federation of March 30, 2015 n 295 "On Approval of the Federal State Educational Standard for Higher Education in the direction of training 19.04.05 High-Tech Production of Functional and Specialized Food Products (Magistracy Level)"; Order of the Ministry of Education of Russia, 2017/08/23 No 816 "On the approval of the procedure for the application of organizations engaged in educational activities, E-learning, distance educational technologies in implementation of educational programs" (Registered in Ministry of Justice of Russia 2017/09/18 No 48226); Order of the National Agency for the Development of Qualifications dated June 26, 2020 No. 42/20-PR "On Approval of Qualification Names and Requirements for Qualifications of the Agro-Industrial Complex"; Letter of the Ministry of Education of the Russian Federation dated March 19, 2020 N GD-39/04 "On the direction of methodological recommendations"; Letter of the Ministry of Education of the Russian Federation dated October 12, 2020 N GD$1736 / 03$ "On recommendations for the use of information technologies"; Letter of the Ministry of Education of the Russian Federation dated November 16, 2020 N GD-2072/03 "On sending recommendations"; Information of the Ministry of Science and Higher Education of the Russian Federation dated November 17, 2020 "Valery Falkov gave explanations on the organization of remote education at universities."

Research methods: cluster analysis, content analysis, generalization, comparative analysis, interpretation. 


\section{Results and discussion.}

At the first stage of the study, we analyzed official documents on the use of the " Flipped Class " blended learning technology in the higher vocational education system in the Russian Federation. We came to the conclusion that according to paragraph 1 of Article 16 of the Federal Law "On Education in the Russian Federation" dated 29.12.2012 N 273-FZ, adopted by the State Duma on December 21, 2012 and approved by the Federation Council on December 26, 2012, (ed. From 31.07.2020) (with rev. and add., came into force since 01.09.2020), the implementation of educational programs using e-learning and remote educational technologies is understood as the organization of educational activities using information contained in databases and implemented in the educational programs. It is provided with information technologies, technical means, as well as information and telecommunication networks, which ensures both the transmission of this information through communication nets, and interaction between students and educators. Remote educational technologies refer to the educational technologies implemented mainly with the use of information and telecommunication networks with indirect (at a distance) interaction between students and pedagogical workers [5]. This promotes an integrated approach to the blended learning, taking into account all aspects of the professional development of the future specialists. In our opinion, such an approach is also a condition for the formation of a reliable assessment of the sustainability of the development of the competitiveness of a future specialist. The qualification category of a specialist in any field is evaluated in terms of the levels of professional competence that characterizes the readiness of a specialist for professional activity.

So, for example, analyzing the Federal State Educational Standard of Higher Education for 19.04.05 High-Tech Production of Functional and Specialized Food Products (master's level) [6], we came to the conclusion that future specialists of the agro-industrial complex at an insufficient level form such professional competence as the ability to organize selfemployment in work.

Another example. A certain characteristic of the professional readiness of a teacher is the abilty to take into account the physiological, psychological, national and other characteristics of students when organizing the educational process. These competencies are the indicators of the development of teacher's competitiveness. The analysis of the Federal State Educational Standard of Higher Education (a bachelor's degree) for 44.03.01 "Pedagogical Education" [7] revealed that in the process of assimilating the content of the program, the future teacher forms the ability to organize and manage educational process. However, the ability to work with children of different nationalities and to teach them Russian as a second language is formed insufficiently.

The formation of the above-mentioned professional competencies of future specialists in various fields, in our opinion, will be more effective in case of implementation of blended learning technology into the educational process. The study by S. Belovitskaya, O. Granovskaya, I. Shatokhina says that the use of the " Flipped Class " blended learning technology in the system of higher vocational education will be effective if:

- e-learning methods of teaching are developed;

- the educational process is provided with high-quality electronic educational materials, which can be used both in the traditional face-to-face and digital education [8].

Having studied the Passport of the Labor Code of the Russian Federation dated 30.12.2001 N 197-FZ, adopted by the State Duma on December 21, 2001 and approved by the Council of the Federation on December 26, 2001 (ed. From 31.07.2020) (with changes and additions entered into force since 13.08.2020), we have revealed that the Russian Federation ensures equal opportunities for employees without any discrimination for promotion in work, in accordance with the productivity, qualifications and work experience, 
as well as for training and additional vocational education (as amended by the Federal Law, 02.07.2013, N 185-FZ) [9]. Therefore, the use of the " Flipped Class " blended learning technology in the higher vocational education is one of the factors of improving the vocational training of a future competitive specialist.

According to the analysis of the legal educational documents, presented in the reference legal system ConsultantPlus, Internet versions of the system Garant [10 - 16], we came to conclusion that the professional development of students meeting the current global socioeconomic challenges determines the tasks of higher vocational education. It requires optimal professional development of a future specialist based on legal norms, existing challenges and educational resources.

The designed model of the organization of the educational process in the system of higher vocational education is shown in Figure 2.

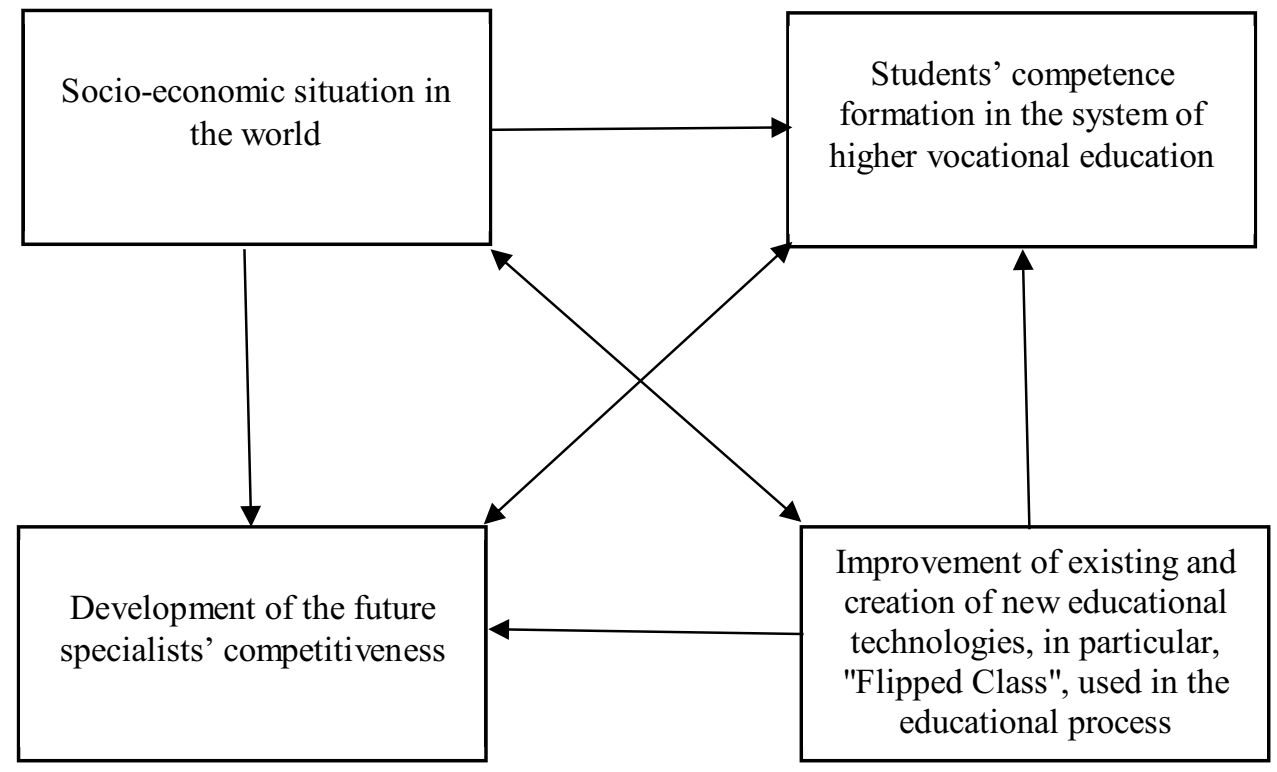

Fig. 2. Model of the organization of the educational process in the system of higher vocational education

The presented model of the educational process's organization in the system of higher professional education using the technology of blended learning "Inverted class" based on the creation of pedagogical conditions is a systematic nature. It takes into account the peculiarities of the socio-economic situation in the world and is based on a level-based approach to the professional development of a competitive specialist. The model presents the objective capabilities of the higher professional education system, determined by the resource educational potential and its quantitative and qualitative implementation in the educational process, which is aimed at ensuring comprehensive professional development in competitive conditions.

The presented model of the organization of the educational process in the system of vocational education meaning the use of the blended learning technology " Flipped Class " and the creation of pedagogical conditions is of a systematic nature. It takes into account the peculiarities of the socio-economic situation in the world and is based on a level-oriented approach to the professional development of a competitive specialist. The model presents the objective capabilities of the higher vocational education, determined by the resource potential and its quantitative and qualitative implementation in the educational process, which is aimed at ensuring students' comprehensive professional development in competitive conditions.

As studies shows, it is the effective organization of the educational process with the use 
of blended learning " Flipped Class" that will save the future specialist from the stressful start of professional activity. And it is obvious that this educational technology contributes to the development of a complex of internal motivation for the profession.

The second stage of the analytical study was aimed at the determining of pedagogical measures on the implementation of the blended learning technology " Flipped Class " into the system of higher vocational education. The professional development of a future competitive specialist was considered.

The pedagogical works by Fedotova O. D. define the direct and indirect effects of students' assimilation of theoretical knowledge and communicative skills used in professional activities. The importance of including students into the educational activities promoting professional identity is revealed $[16,17]$. Thus, we can conclude that a graduate is not always sufficiently ready to carry out professional activities, while in the labor market his work is perceived as providing certain services and requires multi-faceted professional competencies.

The Order of the Russian Ministry of Education No 816, 2017/23/08 "On the approval of the procedure of the use of e-learning, distance learning technologies by the organizations implementing educational programs" [12] presents the characteristic features of the implementation of educational programs or their parts with the help of e-learning, distance learning technologies. The document contains the description of the pedagogical measures for the use of educational technologies. For example, the place of epy implementation of educational activities is the organization's or its branch's location, regardless of the students' location [12]. It is stated that a student may study educational material without being in the classroom, using the scientific, educational and methodological resources of the educational organization. The blended learning technology " Flipped Class " allows to provide educational and methodological assistance to the future specialist, including individual consultations conducted remotely, with the help of information and telecommunication technologies. Students may either independently or through direct interaction with the teacher in the classroom, or with the use of e-learning, distance learning technologies, determine the volume of classes (topics) to learn. These features are schematically presented in Figure 3. 


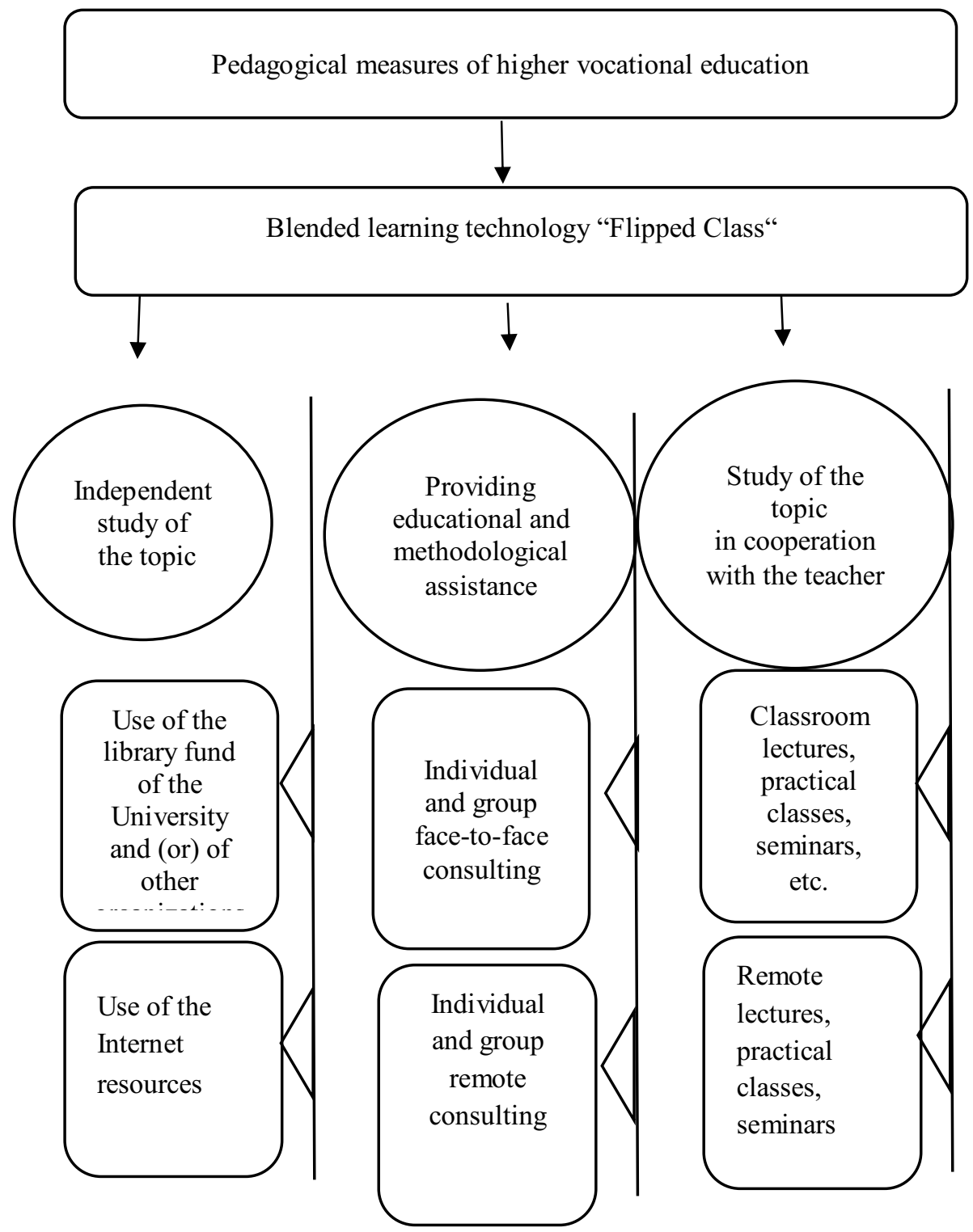

Fig. 3. The scheme of using the blended learning technology "Flipped Class" in the system of higher vocational education

Thus, at the second stage of the study, we came to conclusion that the use of blended learning technology " Flipped Class " in the system of higher vocational education is a special form of professional development of the future competitive specialist. The effectiveness of the application of this technology is as follows:

- future specialists' assimilation of both theoretical knowledge and practical skills of learning process self- organization;

- creating conditions for the effective functioning of the information and educational environment;

- providing professional identification by future specialists;

- monitoring of conducting classes and of students' self-control; 
- achievement and evaluation of learning outcomes by organizing educational activities with face-to-face and e-learning technologies;

- storing the results of the educational process in the electronic form, accessible for the agents of the educational process.

\section{Conclusion}

In accordance with the results of the analysis of both regulatory documents and scientific works by Belovickaya S. I., Brikunova S. S., Fedotova O. D., Guseva T. K., Hitushchenko V. V., Isaeva A. B., Kokodej T. A., M. Lebren, Lomachenko T. I., Mayackaya, N. K., Shatokhina I. V., Shcherbina E. N. [18-22], we observed that the use of blended learning technology "Flipped Class" is currently relevant to the vocational training of future competitive specialists. With the help of this educational technology, the problems of organizing the educational environment aimed at revealing the professional abilities of the future specialists are effectively solved. The use of the "Flipped Class" technology in the vocational education creates pedagogical conditions for the development of students' critical and flexible thinking; openness of judgments; dynamism and plasticity of the quest for knowledge and educational material. The formation of these professional and personal qualities is an integral part of future specialists' professional development.

\section{References}

1. Order of the National Agency for the Development of Qualifications, June, 262020 , No 42/20-PR "On the Approval of the Names and Requirements for Qualifications of the Agro-Industrial Complex (Agricultural Industry)"

2. M. V. Stanislavskaya, M. S. Levkovskaya, Competitiveness of Agricultural Products as One of the Key Factors of the Development of the Industry. CR 17(20), 28-31 (2020) https://apni.ru/article/1164-konkurentosposobnost-produktsii-apk, (last accessed 2021/02/14)

3. L. Johnson, S. Adams Becker, V. Estrada, A. Freeman, Report NMC Horizon: Higher Education - 2015 Austin, 16-17 (Texas: New Media Consortium, 2015)

4. A. Dumont, D. Berthiaume, La pédagogie inversée. Enseigner autrement dans le supérieur avec la classe inversée. De Boeck Supérieur s.a., 235 (2016)

5. Federal Law "On the Education in the Russian Federation" 2012/12/29 No 273-FZ, adopted by the State Duma of 21 December, 2012 and approved by the Federation Council of 26 December, 2012, (edited on June31, 2020) and (with changes and additions entered into force on September 1, 2020).

6. Order of the Russian Ministry of Education 2015/03/30 No 295 "On the Approval of the Federal State Educational Standard of Higher Education for 19.04.05 High-Tech Production of Functional and Specialized Food Products (Master's Degree Level)".

7. Federal State Educational Standard of Higher Education (a bachelor's degree) for 44.03.01 "Pedagogical Education" (Registered with the Russian Federation Justice Ministry 2018/15/03 No 50362), approved by the Order of the Ministry of Education and Science of the Russian Federation on February 22, 2018, N 121.

8. S. I. Belovitskaya, O. V. Granovskaya, I. V. Shatokhina, "Flipped Class" in the Conditions of Professional Formation of Primary School Teachers. TDSE. 66(4), 16-20 (2020) 
9. Labor Code of the Russian Federation 2001/12/30 No 197-FL, adopted by the State Duma on December 21, 2001 and approved by the Federation Council on December 26, 2001 (with changes and additions entered into force on August 13, 2020).

10. Decree of the Russian Federation Government 2020/07/12 No 2040 "Conducting an experiment on the introduction of a digital educational environment" (with the "Regulations on Conducting an Experiment on the Implementation of a Digital Educational Environment on the Territory of Certain Subjects of the Russian Federation").

11. Decree of the Russian Federation Government 2017/12/26 No 1642 (ed. 2020/08/11) "Approval of the Russian Federation the state program "Development of education".

12. Order of the Russian Ministry of Education No 816, 2017/23/08 "On the approval of the procedure of the use of e-learning, distance learning technologies by the organizations implementing educational programs " (Registered in the Ministry of Justice 2017/18/09, No 48226)

13. Letter of the Russian Ministry of Education on March 19, 2020 No GD-39/04 "On the direction of methodological recommendations".

14. Letter of the Russian Ministry of Education on October 12, 2020 No GD-1736/03 "Recommendations for the use of information technologies"; Letter of the Russian Ministry of Education on November 16, 2020 No GD-2072/03 "On the direction of recommendations".

15. Information of the Russian Ministry of Science and Higher Education November 17, 2020 "Valery Falkov gave explanations on the organization of remote training at universities."

16. O. D. Fedotova, Exhibition Activity as a Factor of the Formation of the Professional Identity of Students - Future Primary School Teachers. vth international conference "modern education: vectors of development. the role of social and humanitarian knowledge in teachers' training", 539-547 (2020)

17. O. Fedotova, V. Latun, Flipped learning as alternative pedagogical approach to training of graduate students: advantages and disadvantages. EDULEARN16: 8th international conference on education and new learning technologies, 2919-2925 (Barcelona, SPAIN, 2016)

18. T. I. Lomachenko, T. A. Kokodej, Hitushchenko. Innovative Approaches to the Use of Information and Communication Technologies in the Educational Process in the Digital Economy. BAAEL 1(1), 109-117 (2019)

19. S. I. Belovickaya, A. B. Isaeva, The Formation of Professional Competence of Teachers of Additional Education with the Help of Innovative Educational Technologies. PJ, 4A(10), 232-238 (2020) DOI: 10.34670/AR.2020.35.17.084

20. T. K. Guseva, N. K. Mayatskaya, Russian Teaching as a Socio-Cultural Phenomenon of the Past and the Present. PSFU (PS) 8, 32-38 (2012)

21. I. Shatokhina, V. Integration of the Educational Process. IJAFR 2, 55-56 (2013)

22. S. S. Brikunova, I. V. Shatokhina, E. N. Shcherbina, Experience of Theoretical Substantiation and Practical Implementation in Modern Russian Education of the Future Teachers Training on a Spiritual and Moral Basis. ESSJ 2(18), 118-125 (2012) 